\title{
Impact of variants in CETP and apo Al genes on serum HDL cholesterol levels in men and women from the Polish population
}

\author{
Marta Włodarczyk ${ }^{1}$, Małgorzata Wrzosek ${ }^{1}$, Grażyna Nowicka ${ }^{1}$, Beata Jabłonowska-Lietz ${ }^{2}$
}

\begin{abstract}
${ }^{1}$ Department of Pharmacogenomics, Department of Biochemistry and Clinical Chemistry, Faculty of Pharmacy with Division of Laboratory Medicine, Medical University of Warsaw, Warsaw, Poland

${ }^{2}$ Center of Promotion of Healthy Nutrition and Physical Activity, National Food and Nutrition Institute, Warsaw, Poland
\end{abstract}

Submitted: 29 June 2015

Accepted: 3 November 2015

Arch Med Sci 2016; 12, 6: 1188-1198

DOI: 10.5114 /aoms.2016.60870

Copyright @ 2016 Termedia \& Banach

\section{Abstract}

Introduction: Polymorphisms in the cholesterol ester transfer protein (CETP) gene and apolipoprotein $\mathrm{Al}$ (apo $\mathrm{Al}$ ) gene are identified as the most common genetic factors influencing high-density lipoprotein cholesterol (HDL cholesterol) levels. Low HDL cholesterol is an important risk factor for cardiovascular disease. We investigated the effect of the TaqlB polymorphism of the CETP gene and the 75G/A polymorphism of the apo Al gene on the HDL cholesterol concentration in a sample of Polish adults.

Material and methods: A total of 621 subjects, 414 women and 207 men, were included in this study. Lipid levels were measured using standard protocols, and apolipoprotein Al was determined by immunoturbidimetric assay. CETP and apo Al genotyping was performed using a restriction fragment length polymorphism based method.

Results: Significantly lower HDL cholesterol concentrations were found in B1B1 homozygotes than in carriers of the B2 allele of the TaqlB polymorphism in the CETP gene among both men and women. In GG homozygotes of the $75 \mathrm{G} / \mathrm{A}$ polymorphism in the apo Al gene lower $\mathrm{HDL}$ cholesterol levels were observed, but the difference did not reach statistical significance. A statistically significant association of low HDL cholesterol $\left(<25^{\text {th }}\right.$ percentile) with CETP genotypes was found in women $(p<0.0001)$ and in men $(p=0.0368)$. Conclusions: These data demonstrate a significant impact of the TaqIB polymorphism in the CETP gene on HDL cholesterol levels in the studied Polish population, while the effect of the $75 \mathrm{G} / \mathrm{A}$ polymorphism in the apo Al gene appears not to be significant.

Key words: high-density lipoprotein cholesterol, cholesterol ester transfer protein, apolipoprotein Al, gene polymorphism.

\section{Introduction}

The role of lipoproteins in pathogenesis of atherosclerosis and the association of lipid profile with the risk of cardiovascular disease (CVD) and myocardial infarction (MI) is well accepted $[1,2]$. In clinical practice CVD risk assessment is based on a positive association of low-density lipoprotein cholesterol (LDL cholesterol) and an inverse association of high-density lipoprotein cholesterol (HDL cholesterol) with disease development

\author{
Corresponding author: \\ Marta Włodarczyk \\ Department \\ of Pharmacogenomics \\ Department of Biochemistry \\ and Clinical Chemistry \\ Faculty of Pharmacy \\ with Division \\ of Laboratory Medicine \\ Medical University of Warsaw \\ 1B Banacha St \\ 02-903 Warsaw, Poland \\ Phone: +48 608596674 \\ E-mail: marta.wlodarczyk@ \\ wum.edu.pl
}


and occurrence of clinical events [3, 4]. Nowadays, however, despite recognition of the atheroprotective properties of high-density lipoproteins, the influence of a rise in HDL cholesterol on CVD and $\mathrm{MI}$ risk is questioned [5-7]. There is no doubt that the relation between HDL and cardiovascular risk depends on the functional properties of $\mathrm{HDL}$ particles, and plasma HDL cholesterol concentration is not a marker of HDL function but a result of various processes of the complex metabolism of $\mathrm{HDL}$ particles [8]. However, measurement of $\mathrm{HDL}$ cholesterol concentration is recommended for assessment of CVD risk and efficiency of hyperlipoproteinemia treatment [9]. Therefore, to improve our understanding of lower and increased HDL cholesterol levels, new data are needed, which on one hand will describe the association between different HDL functions and HDL cholesterol concentrations, and on the other hand will enhance our knowledge on the impact of both genetic and environmental factors on HDL cholesterol in different populations.

Various genetic loci have been identified to affect plasma HDL cholesterol concentrations. However, some genome-wide association studies have suggested that the cholesterol ester transfer protein (CETP) locus with the TaqIB polymorphism is much more significant than any other locus correlated with $\mathrm{HDL}$ cholesterol levels [10, 11]. A metaanalysis also revealed an association of the 75G/A polymorphism in the apolipoprotein Al gene (apo Al) with an increase in plasma apo Al levels, but mainly in men [12]. In addition, environmental factors can significantly influence HDL metabolism and reduce or enhance plasma HDL cholesterol concentrations [13]. An interaction between obesity and genetic factors related to HDL cholesterol levels is also of importance [14]. Deficiency of CETP caused by mutations in the CETP gene is characterized by increased HDL cholesterol, but its relation to CVD risk is not clear [15]. Anti-atherogenic and pro-atherogenic activity of CETP in plasma has been considered. CETP activity influences reverse cholesterol transport and also a pool of lipoproteins known to be associated with atherosclerosis. So far, CETP inhibitors besides increasing HDL cholesterol have not been found to be associated with cardiovascular benefit [16, 17]. Although large epidemiological studies have been conducted, the role of CETP in the development of atherosclerosis is still unclear. CETP polymorphisms associated with reduced CETP mass and activity were related to a decrease in cardiovascular risk [18-20]. On the other hand, the same genetic variants which showed reduced CETP levels and increased HDL cholesterol levels have been shown to be associated with increased coronary mortality in statin-treated coronary artery disease patients [21].
The aim of the present study was to assess the frequency of CETP TaqIB and 75G/A apo Al genetic variants and their effects on serum HDL cholesterol concentrations in Polish men and women as well as the influence of the interaction between these genetic variants, obesity and hypertriglyceridemia on HDL cholesterol.

\section{Material and methods}

\section{Study population and clinical investigation}

For the study 621 unrelated adults of Polish nationality were consecutively recruited on the basis of clinical investigation from subjects who had been directed between September 2011 and December 2014 to the Outpatient Clinic at the National Food and Nutrition Institute in Warsaw for routine general health screening or due to obesity. All participants underwent a through medical evaluation including complete health history and physical examination. Data on blood pressure, height, weight, smoking and medical history were collected. The recruited subjects fulfilled the following criteria: had no signs or symptoms of thyroid or other endocrine diseases, renal and hepatic disorders, were-non diabetic, had no history of alcoholism, myocardial infarction or stroke, their body mass index (BMI) was $<35 \mathrm{~kg} / \mathrm{m}^{2}$, and within the last 3 months before the study were not receiving medications known to influence plasma lipid levels (and women did not use hormonal therapy) as well as anti-inflammatory drugs. Postmenopausal status was defined as age at least 55 years and no natural menses at least 6 months before study entry. Increased serum lipid levels, $\mathrm{BMI}$ in the range $25-34 \mathrm{~kg} / \mathrm{m}^{2}$, and hypertension did not exclude subjects from the study. Written informed consent was obtained from each individual before participation in the study. The study protocol was approved by the Ethics Committee at the National Food and Nutrition Institute in Warsaw and was in accordance with the principles of the Declaration of Helsinki.

Blood was collected after overnight fasting. Concentrations of serum total cholesterol, HDL cholesterol and triglycerides (TG) were determined using routine laboratory methods on a biochemical analyzer. The LDL cholesterol levels were calculate using the Friedewald formula. In the serum samples the levels of apo Al were measured using monoclonal antibodies against apo Al (Pointe Scientific) by the immunoturbidimetric method.

\section{DNA genotyping}

DNA was extracted from the leukocytes of the whole blood by the DNA isolation kit (A\&A Biotechnology, Poland). The TaqlB polymorphism (rs708272) in intron 1 of the CETP gene and 
75G/A polymorphism (rs670) of the apo Al gene were detected by a polymerase chain reaction (PCR)-based method using primers described previously $[22,23]$. For the CETP TaqIB polymorphism the amplification mixture included 25 pmol of each primer, $100 \mathrm{ng}$ of genomic DNA, $0.2 \mathrm{mmol} / \mathrm{l}$ of each dNTP, $1.5 \mathrm{mM} \mathrm{MgCl}_{2}$, and $0.2 \mathrm{U}$ Taq polymerase (BioTaq, Bioline Reagents, UK) in a total volume of $25 \mu \mathrm{l}$. Amplification was performed for 35 cycles of $1 \mathrm{~min}$ at $94^{\circ} \mathrm{C}, 30 \mathrm{~s}$ at $64^{\circ} \mathrm{C}$, and $1.5 \mathrm{~min}$ at $72^{\circ} \mathrm{C}$ with an initial denaturation period of 4 min. $20 \mu \mathrm{l}$ of PCR products was digested with the restriction enzyme Taql according to the recommendations of the supplier (Roche Diagnostics $\mathrm{GmbH}$, Germany). Fragments were separated on $2.5 \%$ agarose gel (SeaKem LE Agarose, Lonza, USA) and stained with ethidium bromide. One fragment of $505 \mathrm{bp}$ indicated the absence of the Taql restriction site (B2B2 genotype), two fragments of 415 and $90 \mathrm{bp}$ indicated the presence of the restriction site (B1B1), and three fragments of 505,415 , and 90 bp indicated heterozygosity for the restriction site (B1B2).

For the apo Al 75G/A polymorphism $25 \mu \mathrm{l}$ of reaction volume contained $50 \mathrm{ng}$ of genomic DNA, a PCR buffer with $1.5 \mathrm{mM} \mathrm{MgCl}, 0.01 \mathrm{mM}$ dNTP, $100 \mu \mathrm{M}$ of both primers, and $1 \mathrm{U}$ of Taq DNA polymerase (Fermentas, Lithuania). Amplification conditions used with the gradient thermal cycler (MJ Research, USA) were as follows: an initial incubation at $94^{\circ} \mathrm{C}$ for $5 \mathrm{~min}$, followed by 35 cycles of incubation at $94^{\circ} \mathrm{C}$ for $1 \mathrm{~min}, 60^{\circ} \mathrm{C}$ for $30 \mathrm{~s}$ and $72^{\circ} \mathrm{C}$ for $30 \mathrm{~s}$, with a final extension at $72^{\circ} \mathrm{C}$ for $5 \mathrm{~min}$. The PCR product was digested overnight with $3 \mathrm{U}$ of the Mspl enzyme (Roche Diagnostics $\mathrm{GmbH}$, Germany); digested fragments were separated on 3\% agarose gel, stained with ethidium bromide, and visualized under UV light. Fragments of 209 and $179 \mathrm{bp}$ indicated the absence of the Mspl restriction site (AA genotype), fragments of 209 and $113 \mathrm{bp}$ indicated the presence of the restriction site (GG), and fragments of 209, 179 and $113 \mathrm{bp}$ indicated heterozygosity for the restriction site (GA).

\section{Statistical analysis}

Data were presented as mean and SD. Ranges of HDL cholesterol and apolipoprotein Al concentrations were obtained as the $25^{\text {th }}$ and $75^{\text {th }}$ percentile determined separately for women and men. Allele frequencies were assessed by the gene-counting method. Chi-square $\left(\chi^{2}\right)$ analysis was used to estimate the Hardy-Weinberg equilibrium and to compare genotypic and allelic frequencies among the study groups. One-way ANOVA was used in the analysis between groups which were normally distributed while the Kruskal-Wallis test was used in the absence of normal distribution. Qualitative variables were coded as 0-1 dummy variables. Odds ratios (ORs) (crude and adjusted for confounding factors) were calculated for low HDL $\left(<25^{\text {th }}\right.$ percentile) and high $\mathrm{HDL}\left(>75^{\text {th }}\right.$ percentile), and among both genders. The following confounding factors were taken into account: smoking, obesity, menopause, hypertriglyceridemia (TG > 200/dl), hypercholesterolemia (total cholesterol $\geq 200 \mathrm{mg} / \mathrm{dl}$ ), apolipoprotein Al $<25^{\text {th }}$ percentile, $75 \mathrm{G} / \mathrm{A}$ and CETP gene polymorphism. Of them, CETP gene polymorphism, obesity, TG $>200 \mathrm{mg} / \mathrm{dl}$ and $\mathrm{Apo} \mathrm{Al}<25^{\text {th }}$ percentile were statistically significant (crude analysis) and thus remained in the adjusted regression model. Adjusted logistic regression was used to test whether the effect of B1B1 genotype of CETP gene polymorphism influenced the incidence of low HDL cholesterol $\left(<25^{\text {th }}\right.$ percentile) in the presence of confounders (obesity, TG $>200 \mathrm{mg} / \mathrm{dl}$ and Apo Al $<25^{\text {th }}$ percentile). Separately, adjusted logistic regression was used to confirm the effect of the B2 allele of the CETP polymorphism on incidence of high $\mathrm{HDL}$ cholesterol ( $>75^{\text {th }}$ percentile) in the presence of confounders (BMI $<30 \mathrm{~kg} / \mathrm{m}^{2}, \mathrm{TG} \leq$ $200 \mathrm{mg} / \mathrm{dl}$ and Apo Al $>75^{\text {th }}$ percentile).

Results from the logistic regression model are presented as ORs with 95\% confidence intervals (Cls). A two-tailed $p$-value of $p<0.05$ was considered statistically significant. The Statistica software package version 10 was used for the statistical analysis.

\section{Results}

Table I provides a summary of the demographic and biochemical characteristics of the study participants: 621 subjects, 207 (33\%) men and 414 (67\%) women.

The frequencies of genotypes and alleles of the 75G/A polymorphism in the apo Al gene and the TaqIB polymorphism in the CETP gene in the studied group are presented in Table II. The distributions of genotypes of both variants did not deviate from Hardy-Weinberg equilibrium $(p>0.05)$. There was no statistically significant difference in the frequency of alleles and genotypes according to gender, BMI, smoking or menopausal status (data not shown). In additional statistical analysis, no significant difference in frequency of GG homozygosity in the 75G/A polymorphism among women with the B2 allele as compared to women with the B1B1 genotype was found ( $p=0.481)$.

No significant differences in lipids, lipoproteins and apolipoprotein Al levels between GG homozygotes and carriers of the A allele of the $75 \mathrm{G} / \mathrm{A}$ polymorphism in the apo Al gene were observed among both men and women (Table III). However, among women GG homozygotes were characterized by about $11 \%$ lower apo Al concen- 
Table I. Demographic and biochemical characteristics of the study group

\begin{tabular}{|c|c|c|c|}
\hline Parameter & $\begin{array}{c}\text { All } \\
\text { subjects }\end{array}$ & Women & Men \\
\hline$N(\%)$ & 621 & $414(67)$ & 207 (33) \\
\hline Age [years] & $46 \pm 14$ & $46 \pm 13$ & $46 \pm 14$ \\
\hline Height $[\mathrm{cm}]$ & $168 \pm 19$ & $163 \pm 6$ & $178 \pm 7^{*}$ \\
\hline Weight [kg] & $75 \pm 16$ & $70 \pm 13$ & $87 \pm 15^{*}$ \\
\hline $\mathrm{BMI}\left[\mathrm{kg} / \mathrm{m}^{2}\right]$ & $27 \pm 4$ & $26 \pm 5$ & $28 \pm 4^{\star}$ \\
\hline $\mathrm{SBP}[\mathrm{mm} \mathrm{Hg}]$ & $124 \pm 15$ & $122 \pm 15$ & $129 \pm 13^{*}$ \\
\hline $\mathrm{DBP}[\mathrm{mm} \mathrm{Hg}]$ & $78 \pm 10$ & $76 \pm 10$ & $82 \pm 10^{*}$ \\
\hline Triglycerides [mg/dl] & $116 \pm 61$ & $104 \pm 50$ & $141 \pm 72^{*}$ \\
\hline $\begin{array}{l}\text { Total cholesterol } \\
{[\mathrm{mg} / \mathrm{d}]}\end{array}$ & $196 \pm 36$ & $197 \pm 35$ & $195 \pm 36$ \\
\hline $\begin{array}{l}\text { HDL cholesterol } \\
{[\mathrm{mg} / \mathrm{dl}]}\end{array}$ & $56 \pm 14$ & $60 \pm 14$ & $47 \pm 10^{\star}$ \\
\hline $\begin{array}{l}\text { LDL cholesterol } \\
{[\mathrm{mg} / \mathrm{dl}]}\end{array}$ & $116 \pm 33$ & $115 \pm 32$ & $119 \pm 33$ \\
\hline $\begin{array}{l}\text { Apolipoprotein Al } \\
\text { [mg/dl] }\end{array}$ & $152 \pm 33$ & $157 \pm 33$ & $140 \pm 28^{*}$ \\
\hline Glucose $[\mathrm{mg} / \mathrm{dl}]$ & $86 \pm 12$ & $85 \pm 12$ & $91 \pm 12^{*}$ \\
\hline HDL-C/Apo Al & $\begin{array}{c}0.3786 \\
\pm 0.0814\end{array}$ & $\begin{array}{c}0.3882 \\
\pm 0.0808\end{array}$ & $\begin{array}{c}0.3587 \\
\pm 0.0794^{*}\end{array}$ \\
\hline TG/HDL-C & $\begin{array}{l}2.3087 \\
\pm 1.754 \\
\end{array}$ & $\begin{array}{r}3.126 \\
\pm 2.094 \\
\end{array}$ & $\begin{array}{c}1.899 \\
\pm 1.389^{\star}\end{array}$ \\
\hline AIP & $\begin{array}{l}-0.0956 \\
\pm 0.2589 \\
\end{array}$ & $\begin{array}{c}-0.1521 \\
\pm 0.242\end{array}$ & $\begin{array}{c}0.0223 \\
\pm 0.254^{*}\end{array}$ \\
\hline
\end{tabular}

Data are presented as mean $\pm S D$. SBP, DBP - systolic and diastolic blood pressure. AIP (Atherogenic Index of Plasma) was calculated according to the following formula: $A I P=\log (T G \mathrm{mmol}) /(\mathrm{HDL}$ $\mathrm{mmol}$. Ratio $T G / \mathrm{HDL}-\mathrm{C}$ calculated in $\mathrm{mg} / \mathrm{ml}$. ${ }^{*} \mathrm{p}<0.05$ between men and women, ANOVA or Kruskal-Wallis test was used.

trations as compared to A allele carriers. $71 \%$ of studied women were premenopausal and 29\% were postmenopausal. No significant difference in HDL cholesterol between women before and after menopause was found among GG subjects or among A allele carriers (data not shown). Significantly lower HDL cholesterol concentrations were found in B1B1 homozygotes than in carriers of the B2 allele of the TaqlB polymorphism in the CETP gene among both men and women (Table IV). These differences were not accompanied by any significant differences in serum triglycerides, total cholesterol or apo Al concentrations. In further statistical analyses (data not shown) the significant effect of the TaqIB polymorphism in the CETP gene on HDL cholesterol was observed in both premenopausal ( $p=0.003$ ) and postmenopausal women $(p=0.008)$. The $\mathrm{HDL} /$ apo $\mathrm{Al}$ ratio was higher in female B2 allele carriers compared to female B1B1 homozygotes ( $p=0.0422)$, while in male study participants no statistically significant difference was found (Table IV).
Table II. CETP and apo Al genotype distribution and allele frequencies in studied group

\begin{tabular}{|lccc|}
\hline Genotype & $\begin{array}{c}\text { All } \\
\text { subjects, } \\
n(\%) \\
N=621\end{array}$ & $\begin{array}{c}\text { Women, } \\
n(\%)\end{array}$ & $\begin{array}{c}\text { Men, } \\
n(\%)\end{array}$ \\
\hline \begin{tabular}{l} 
CETP: \\
\hline B1B1
\end{tabular} & $220(35)$ & $139(33)$ & $81(39)$ \\
\hline B1B2 & $303(49)$ & $202(49)$ & $101(49)$ \\
\hline B2B2 & $98(16)$ & $73(18)$ & $25(12)$ \\
\hline $\begin{array}{l}\text { Frequency of the } \\
\text { B2 allele }\end{array}$ & 0.402 & 0.420 & 0.365 \\
\hline$\chi^{2}=0.1401 ; p=0.708$ & & & \\
\hline Apo Al: & & & \\
\hline GG & $376(61)$ & $247(60)$ & $129(63)$ \\
\hline GA & $201(33)$ & $133(33)$ & $68(33)$ \\
\hline AA & $38(6)$ & $30(7)$ & $8(4)$ \\
\hline $\begin{array}{l}\text { Frequency of the } \\
\text { A allele }\end{array}$ & 0.225 & 0.235 & 0.205 \\
\hline$\chi^{2}=2.476 ; p=0.1155$ & & & \\
\hline Pearson's $\chi^{2}$ analysis was used & & \\
\hline
\end{tabular}

Pearson's $\chi^{2}$ analysis was used.

It is well known that HDL metabolism is related to the metabolism of triglyceride-rich lipoproteins and lower serum HDL cholesterol concentrations occur in subjects with hypertriglyceridemia [9, 24]. In the whole group $9 \%$ of subjects were hypertriglyceridemic (serum TG > $200 \mathrm{mg} / \mathrm{dl}$, according to [25]), 5\% among women and 17\% among men. The ratio between serum triglycerides and HDL cholesterol was calculated and presented as TG/HDL-C (concentrations expressed in $\mathrm{mg} / \mathrm{dl}$ ) and also as the atherogenic index of plasma (AIP) calculated according to the following formula AIP $=\log (\mathrm{TG}) /(\mathrm{HDL})$, where both serum triglycerides and HDL cholesterol concentrations were expressed in molar concentrations [26]. In the studied males significantly higher AIP was observed in B1B1 homozygotes compared to B2 allele carriers $(p=0.0412)$, while no differences were noted in women (Table IV). The commonly used TG/HDL ratio was significantly higher in B1B1 homozygotes compared to B2 allele carriers $(p=0.0348$ among women and $p=0.0258$ among men). No association between 75G/A polymorphism of the apo Al gene and AIP or TG/HDL was found (Table III).

We analyzed the association of CETP TaqIB variants and apo Al-75G/A variants with HDL cholesterol concentrations lower than the $25^{\text {th }}$ percentile, between the $25^{\text {th }}$ and $75^{\text {th }}$, and higher than the $75^{\text {th }}$ percentile of the HDL cholesterol range observed, separately in studied men and women. For CETP TaqIB variants a significant association 
Marta Włodarczyk, Małgorzata Wrzosek, Grażyna Nowicka, Beata Jabłonowska-Lietz

Table III. Association of 75G/A polymorphism of apo Al gene with lipid profile

\begin{tabular}{|c|c|c|c|c|}
\hline \multirow[t]{2}{*}{ Parameter } & \multicolumn{2}{|c|}{$\begin{array}{l}\text { Women } \\
N=414\end{array}$} & \multicolumn{2}{|c|}{$\begin{array}{c}\text { Men } \\
N=207\end{array}$} \\
\hline & $\begin{array}{c}\text { A allele carriers } \\
(\mathrm{GA}+\mathrm{AA}) \\
n=163\end{array}$ & $\begin{array}{c}\text { GG } \\
n=247\end{array}$ & $\begin{array}{c}\text { A allele carriers } \\
(\mathrm{GA}+\mathrm{AA}) \\
n=76\end{array}$ & $\begin{array}{c}\text { GG } \\
n=129\end{array}$ \\
\hline Age [years] & $47 \pm 14$ & $45 \pm 13$ & $46 \pm 14$ & $46 \pm 13$ \\
\hline $\mathrm{BMI}\left[\mathrm{kg} / \mathrm{m}^{2}\right]$ & $26 \pm 5$ & $26 \pm 5$ & $27 \pm 4$ & $28 \pm 4$ \\
\hline $\mathrm{SBP}[\mathrm{mm} \mathrm{Hg}]$ & $122 \pm 15$ & $121 \pm 14$ & $131 \pm 13$ & $128 \pm 13$ \\
\hline $\mathrm{DBP}[\mathrm{mm} \mathrm{Hg}]$ & $76 \pm 11$ & $76 \pm 10$ & $83 \pm 10$ & $82 \pm 10$ \\
\hline Triglycerides [mg/dl] & $105 \pm 54$ & $103 \pm 48$ & $144 \pm 78$ & $136 \pm 67$ \\
\hline Total cholesterol [mg/dl] & $198 \pm 36$ & $196 \pm 35$ & $196 \pm 39$ & $193 \pm 34$ \\
\hline HDL cholesterol [mg/dl] & $62 \pm 14$ & $59 \pm 14$ & $48 \pm 11$ & $47 \pm 10$ \\
\hline LDL cholesterol [mg/dl] & $115 \pm 33$ & $115 \pm 32$ & $119 \pm 35$ & $119 \pm 31$ \\
\hline Apolipoprotein Al [mg/dl] & $162 \pm 34$ & $155 \pm 33$ & $144 \pm 28$ & $138 \pm 29$ \\
\hline HDL-C/Apo Al & $0.392 \pm 0.079$ & $0.386 \pm 0.082$ & $0.360 \pm 0.074$ & $0.358 \pm 0.083$ \\
\hline TG/HDL-C & $1.904 \pm 1.577$ & $1.899 \pm 1.264$ & $3.294 \pm 2.296$ & $2.986 \pm 1.950$ \\
\hline AIP & $-0.164 \pm 0.144$ & $0.237 \pm 0.245$ & $0.009 \pm 0.267$ & $0.0292 \pm 0.249$ \\
\hline
\end{tabular}

Data are presented as mean $\pm S D$. SBP, DBP - systolic and diastolic blood pressure. AIP (Atherogenic Index of Plasma) was calculated according to the following formula: AIP $=\log (T G \mathrm{mmol}) /(\mathrm{HDL} \mathrm{mmol})$. Ratio TG/HDL-C calculated in $\mathrm{mg} / \mathrm{ml}$. Differences between $A$ allele carriers and GG homozygotes were not statistically significant; ANOVA or Kruskal-Wallis test was used.

Table IV. Summary for the biochemical parameters in different variants of CETP-Taql polymorphisms

\begin{tabular}{|c|c|c|c|c|}
\hline \multirow[t]{2}{*}{ Parameter } & \multicolumn{2}{|c|}{$\begin{array}{l}\text { Women } \\
N=414\end{array}$} & \multicolumn{2}{|c|}{$\begin{array}{c}\text { Men } \\
N=207\end{array}$} \\
\hline & $\begin{array}{c}\text { B1B1 } \\
n=139\end{array}$ & $\begin{array}{c}\text { B2 allele carriers } \\
\text { (B1B2 + B2B2) } \\
n=275\end{array}$ & $\begin{array}{l}\text { B1B1 } \\
n=81\end{array}$ & $\begin{array}{c}\text { B2 allele carriers } \\
\text { (B1B2 + B2B2) } \\
n=126\end{array}$ \\
\hline Age [years] & $45 \pm 13$ & $46 \pm 13$ & $46 \pm 14$ & $46 \pm 14$ \\
\hline $\mathrm{BMI}\left[\mathrm{kg} / \mathrm{m}^{2}\right]$ & $26 \pm 5$ & $26 \pm 5$ & $28 \pm 4$ & $27 \pm 4$ \\
\hline $\mathrm{SBP}[\mathrm{mm} \mathrm{Hg}]$ & $121 \pm 15$ & $121 \pm 15$ & $128 \pm 12$ & $130 \pm 13$ \\
\hline $\mathrm{DBP}[\mathrm{mm} \mathrm{Hg}]$ & $76 \pm 10$ & $78 \pm 10$ & $81 \pm 10$ & $83 \pm 10$ \\
\hline Triglycerides [mg/dl] & $109 \pm 53$ & $103 \pm 49$ & $148 \pm 75$ & $134 \pm 70$ \\
\hline Total cholesterol [mg/dl] & $193 \pm 35$ & $199 \pm 35$ & $193 \pm 36$ & $196 \pm 36$ \\
\hline HDL cholesterol [mg/dl] & $57 \pm 13$ & $62 \pm 13^{*}$ & $45 \pm 9$ & $49 \pm 11^{*}$ \\
\hline LDL cholesterol [mg/dl] & $114 \pm 32$ & $116 \pm 33$ & $118 \pm 34$ & $120 \pm 32$ \\
\hline Apolipoprotein Al [mg/dl] & $153 \pm 36$ & $160 \pm 32$ & $135 \pm 29$ & $143 \pm 28$ \\
\hline Glucose $[\mathrm{mg} / \mathrm{dl}]$ & $84 \pm 13$ & $85 \pm 12$ & $92 \pm 12$ & $90 \pm 12$ \\
\hline HDL-C/Apo Al & $0.374 \pm 0.075$ & $0.396 \pm 0.083^{*}$ & $0.351 \pm 0.078$ & $0.364 \pm 0.081$ \\
\hline TG/HDL-C & $2.102 \pm 1.438$ & $1.797 \pm 1.355^{\star}$ & $3.522 \pm 2.349$ & $2.861 \pm 1.868^{\star}$ \\
\hline AIP & $-0.117 \pm 0.276$ & $-0.171 \pm 0.22$ & $0.082 \pm 0.284$ & $-0.015 \pm 0.228^{*}$ \\
\hline
\end{tabular}

Data are presented as mean $\pm S D$. SBP, DBP - systolic and diastolic blood pressure. AIP (Atherogenic Index of Plasma) was calculated according to the following formula: $A I P=\log (T G \mathrm{mmol}) /\left(\mathrm{HDL}\right.$ mmol). Ratio $T G / H D L-C$ calculated in $\mathrm{mg} / \mathrm{ml}$. ${ }^{*} p<0.05$; differences between B2 allele carriers and B1B1 homozygotes; ANOVA or Kruskal-Wallis test was used. 
was found in women $(p<0.00001)$ and in men $(p=0.0368)$ (Table V). No association of apo Al75G/A variants with HDL cholesterol percentile ranges was observed (data not shown).

Obesity is known to disturb lipid metabolism and, as expected, lower HDL cholesterol concentrations were found in studied obese subjects than in non-obese subjects. Statistically significant differences in HDL cholesterol were observed between obese and non-obese men $(p=0.02$; $44 \pm 9 \mathrm{mg} / \mathrm{dl}$ vs. $50 \pm 11 \mathrm{mg} / \mathrm{dl}$, respectively) and women ( $p=0.001 ; 54 \pm 13 \mathrm{mg} / \mathrm{dl}$ vs. $63 \pm 13 \mathrm{mg} / \mathrm{dl}$, respectively). However, obese and non-obese B2 allele carriers of both sexes had higher HDL cholesterol concentrations than carriers of the B1B1 genotype $(p=0.161$ for obese men and $p=0.016$ for obese women; $p=0.041$ for non-obese men and $p=0.033$ for non-obese women). Separate analyses performed for obese and non-obese men and women revealed that non-obese women with the A allele (75G/A polymorphism in the apo Al gene) had significantly $(p=0.027)$ higher HDL cholesterol levels than non-obese GG homozygotes, while no differences in obese women $(p=0.130)$ and in men (either obese $(p=0.142)$ or non-obese $(p=0.261))$ were found.

Crude logistic regression analysis (Table VI) showed that B1B1 homozygotes had 2.36 times (95\% Cl: $1.62-3.45)$ higher odds of having low $\mathrm{HDL}$ cholesterol $\left(<25^{\text {th }}\right.$ percentile) than B2 allele carriers, and female B1B1 homozygotes had 3.18 times higher odds (95\% Cl: 1.99-5.05) while male B1B1 homozygotes had 1.32 times higher odds of having low $\mathrm{HDL}$ cholesterol (95\% Cl: 0.68-2.59). Hypertriglyceridemia (serum TG > 200 mg/dl) sig- nificantly increased the risk of low HDL cholesterol $(\mathrm{OR}=4.42,95 \% \mathrm{Cl}: 2.51-7.77)$. Mean serum triglyceride concentrations were higher in men than in women (141 $\pm 72 \mathrm{mg} / \mathrm{dl}$ vs. $104 \pm 50 \mathrm{mg} / \mathrm{dl}$, $p<0.05$ ), but occurrence of hypertriglyceridemia (serum TG $>200 \mathrm{mg} / \mathrm{dl}$ ) was associated with more than 3 times higher chance of having low $\mathrm{HDL}$ cholesterol in women $(\mathrm{OR}=11.42,95 \% \mathrm{Cl}$ : 4.06$32.17)$ than in men $(\mathrm{OR}=3.06,95 \% \mathrm{Cl}: 1.38-6.65)$. As expected, obesity significantly enhances the risk of low HDL cholesterol: in the whole sample $(\mathrm{OR}=2.61,95 \% \mathrm{Cl}: 1.75-3.86)$ and in men $(\mathrm{OR}=$ 2.03, 95\% Cl: 1.01-4.09) and women $(\mathrm{OR}=3.00$, $95 \% \mathrm{Cl}: 1.87-4.83$ ). Low apo Al concentration (apo $\mathrm{Al}<25^{\text {th }}$ percentile) also significantly increased the risk - in the whole sample OR $=4.40(95 \% \mathrm{Cl}$ : 2.56-7.54), in women OR $=4.29$ (95\% Cl: $2.26-$ 8.14) and in men $\mathrm{OR}=4.94$ (95\% Cl: $1.76-13.86)$ - while no statistically significant influence of the 75G/A polymorphism in the apo Al gene was recognized. Variables that were significantly associated with low HDL cholesterol in univariable models were then used in multivariable logistic regression analysis. Multivariable logistic regression analysis revealed that all these variables influenced the risk of having low HDL cholesterol $\left(<25^{\text {th }}\right.$ percentile), and a significant impact $(p=0.000)$ of B1B1 homozygosity after adjustment for apo Al, BMI and hypertriglyceridemia was noted in women (Table VI). Additionally, in women the impact of high serum triglycerides on HDL cholesterol concentration was almost four times higher than in men $(\mathrm{OR}=9.41 \mathrm{vs}$. $\mathrm{OR}=2.64)$.

Crude estimates indicated that the B2 allele, high apo $\mathrm{Al}$ concentration ( $>75^{\text {th }}$ percentile), BMI

Table V. Association between high HDL cholesterol ( $>75^{\text {th }}$ percentile) and low HDL cholesterol $\left(<25^{\text {th }}\right.$ percentile) and TaqI CETP genetic variants in women (A) and men (B)

A

\begin{tabular}{|c|c|c|c|}
\hline Women & $\begin{array}{c}\text { HDL-C }>75^{\text {th }} \text { percentile } \\
(>70 \mathrm{mg} / \mathrm{dl}) \\
N=81\end{array}$ & $\begin{array}{c}25^{\text {th }} \text { percentile } \leq \mathrm{HDL}-\mathrm{C} \\
\leq 75^{\text {th }} \text { percentile } \\
(51-70 \mathrm{mg} / \mathrm{dl}) \\
N=231\end{array}$ & $\begin{array}{c}\text { HDL-C }<25^{\text {th }} \text { percentile } \\
(<51 \mathrm{mg} / \mathrm{dl}) \\
N=102\end{array}$ \\
\hline $\begin{array}{l}\text { B1B1 } \\
N=139\end{array}$ & $20(25 \%)$ & $64(28 \%)$ & 55 (54\%) \\
\hline $\begin{array}{l}\text { B2 allele carriers }(B 1 B 2+B 2 B 2) \\
N=275\end{array}$ & $61(75 \%)$ & $167(72 \%)$ & 47 (46\%) \\
\hline
\end{tabular}

Pearson's chi-square $\left(\chi^{2}\right)$ analysis was used, $\chi^{2}=25.368, d f=2, p<0.00001$.

B

\begin{tabular}{|c|c|c|c|}
\hline Men & $\begin{array}{c}\text { HDL-C }>75^{\text {th }} \text { percentile } \\
(>52 \mathrm{mg} / \mathrm{dl}) \\
N=62\end{array}$ & $\begin{array}{c}25^{\text {th }} \text { percentile } \leq \mathrm{HDL}-\mathrm{C} \\
\leq 75^{\text {th }} \text { percentile } \\
(40-52 \mathrm{mg} / \mathrm{dl}) \\
N=100\end{array}$ & $\begin{array}{c}\text { HDL-C }<25^{\text {th }} \text { percentile } \\
(<40 \mathrm{mg} / \mathrm{dl}) \\
N=45\end{array}$ \\
\hline $\begin{array}{l}\text { B1B1 } \\
N=81\end{array}$ & $16(26 \%)$ & $45(45 \%)$ & $20(45 \%)$ \\
\hline $\begin{array}{l}\text { B2 allele carriers (B1B2 + B2B2) } \\
N=126\end{array}$ & $46(74 \%)$ & 55 (55\%) & $25(55 \%)$ \\
\hline
\end{tabular}

Pearson's $\chi^{2}$ analysis was used, $\chi^{2}=6.601, d f=2, p=0.03686$. 
Table VI. Crude estimates and adjusted OR for low HDL cholesterol concentration ( $<25^{\text {th }}$ percentile) among women and men

\begin{tabular}{|c|c|c|c|c|}
\hline \multirow[t]{3}{*}{ Group } & \multicolumn{2}{|c|}{ Unadjusted } & \multicolumn{2}{|c|}{ Adjusted } \\
\hline & \multicolumn{2}{|c|}{ HDL-C $<25^{\text {th }}$ percentile } & \multicolumn{2}{|c|}{ HDL-C $<25^{\text {th }}$ percentile } \\
\hline & OR $(95 \% \mathrm{Cl})$ & $P$-value & OR $(95 \% \mathrm{Cl})$ & $P$-value \\
\hline \multicolumn{5}{|l|}{ All subjects: } \\
\hline CETP B1B1 genotype & $2.36(1.62-3.45)$ & $<0.0001$ & $2.14(1.45-3.18)$ & $<0.0001$ \\
\hline Obesity, BMI $\geq 30 \mathrm{~kg} / \mathrm{m}^{2}$ & $2.61(1.77-3.86)$ & $<0.0001$ & $2.24(1.48-3.37)$ & $<0.0001$ \\
\hline $\mathrm{TG}>200 \mathrm{mg} / \mathrm{dl}$ & $4.42(2.51-7.77)$ & $<0.0001$ & $3.39(1.88-6.12)$ & $<0.0001$ \\
\hline Apo $\mathrm{Al}<25^{\text {th }}$ percentile & $4.40(2.56-7.54)$ & $<0.0001$ & $4.14(2.32-7.40)$ & $<0.0001$ \\
\hline \multicolumn{5}{|l|}{ Women: } \\
\hline CETP B1B1 genotype & $3.18(2.0-5.05)$ & $<0.0001$ & $3.29(2.00-5.39)$ & $<0.0001$ \\
\hline Obesity, BMI $\geq 30 \mathrm{~kg} / \mathrm{m}^{2}$ & $3.00(1.9-4.83)$ & $<0.0001$ & $2.87(1.72-4.80)$ & $<0.0001$ \\
\hline $\mathrm{TG}>200 \mathrm{mg} / \mathrm{dl}$ & $11.42(4.06-32.17)$ & $<0.0001$ & $9.41(3.19-27.74)$ & $<0.0001$ \\
\hline Apo $\mathrm{Al}<25^{\text {th }}$ percentile & $4.29(2.26-8.14)$ & $<0.0001$ & $5.12(2.47-10.59)$ & $<0.0001$ \\
\hline \multicolumn{5}{|l|}{ Men: } \\
\hline CETP B1B1 genotype & $1.32(0.68-2.59)$ & 0.4098 & $1.09(0.54-2.20)$ & 0.8167 \\
\hline Obesity, BMI $\geq 30 \mathrm{~kg} / \mathrm{m}^{2}$ & $2.03(1.01-4.09)$ & 0.005 & $1.60(0.76-3.35)$ & 0.209 \\
\hline $\mathrm{TG}>200 \mathrm{mg} / \mathrm{dl}$ & $3.06(1.38-6.65)$ & 0.005 & $2.64(1.17-5.97)$ & 0.0187 \\
\hline Apo $\mathrm{Al}<25^{\text {th }}$ percentile & $4.94(1.76-13.8)$ & 0.0021 & $4.36(1.48-12.83)$ & 0.0069 \\
\hline
\end{tabular}

$<30 \mathrm{~kg} / \mathrm{m}^{2}$ and serum TG concentration lower than $200 \mathrm{mg} / \mathrm{dl}$ significantly increased the chance of high $\mathrm{HDL}$ cholesterol ( $>75^{\text {th }}$ percentile), and no significant impact of the 75G/A polymorphism in the apo Al gene was confirmed. However, in multivariable logistic regression analysis only high apo $\mathrm{Al}$ range and $\mathrm{BMI}<30 \mathrm{~kg} / \mathrm{m}^{2}$ were found to significantly enhance the chance of having high HDL cholesterol. In the model adjusted for BMI, apo Al and triglycerides, occurrence of the B2 allele did not have a significant impact $(p=0.076)$ on high HDL cholesterol (Table VII).

\section{Discussion}

Cardiovascular disease is the leading cause of death, and a high level of LDL cholesterol is a major risk factor. However, despite adequate control of LDL cholesterol still a substantial number of patients suffer from cardiovascular events [27, 28]. Therefore, alternative targets to reduce residual cardiovascular risk are of great importance [29]. Low HDL cholesterol is well accepted as one of the major risk factors for cardiovascular events [30, 31]. Observational studies have also shown that each $1 \mathrm{mg} / \mathrm{dl}$ rise in HDL cholesterol is associated with a $2-3 \%$ drop in coronary artery disease risk
[32]. Although increased HDL cholesterol concentration caused by CETP deficiency was not found to be a good risk predictor $[15,17,33]$, several CETP genetic variants characterized by high HDL cholesterol were found to be associated with longevity [34]. Involvement of HDL in lipid transport and reverse cholesterol transport and multiple mechanisms of HDL activity outside lipid metabolism make it difficult to relate HDL cholesterol to outcomes affected by HDL functions. Beside levels of HDL cholesterol, other HDL-related biomarkers and the quality of HDL particles have been discussed as more relevant to estimate risk of cardiovascular disease [8, 35]. Also pharmacological therapies for modulating HDL metabolism and functionality have been reviewed recently [4]. In clinical practice HDL cholesterol measurement is commonly used to assess HDL, and nowadays there is no other HDL-related parameter recommended to general practitioners and other physicians. Although different HDL-related measures have been proposed as apo Al concentration or $\mathrm{HDL}$ particle measures by NMR, they are still not recommended and are used in specialized centers [36-38]. Recently, there was developed a clinical NMR instrument that allows HDL particle mea- 
Table VII. Crude estimates and adjusted OR for high HDL-cholesterol concentration ( $>75^{\text {th }}$ percentile) among women and men

\begin{tabular}{|c|c|c|c|c|}
\hline \multirow[t]{3}{*}{ Group } & \multicolumn{2}{|c|}{ Unadjusted } & \multicolumn{2}{|c|}{ Adjusted } \\
\hline & \multicolumn{2}{|c|}{$\mathrm{HDL}-\mathrm{C}>75^{\text {th }}$ percentile } & \multicolumn{2}{|c|}{$\mathrm{HDL}-\mathrm{C}>75^{\text {th }}$ percentile } \\
\hline & OR $(95 \% \mathrm{Cl})$ & $P$-value & OR $(95 \% \mathrm{Cl})$ & $P$-value \\
\hline \multicolumn{5}{|l|}{ All subjects: } \\
\hline CETP B2 allele presence & $1.86(1.22-2.83)$ & 0.0038 & $1.69(0.95-3.02)$ & 0.076 \\
\hline $\mathrm{BMI}<30 \mathrm{~kg} / \mathrm{m}^{2}$ & $2.87(1.72-4.79)$ & 0.0001 & $2.82(1.29-6.20)$ & 0.0097 \\
\hline $\mathrm{TG} \leq 200 \mathrm{mg} / \mathrm{dl}$ & $5.82(1.79-18.96)$ & 0.0034 & $2.87(0.61-13.54)$ & 0.1801 \\
\hline Apo $\mathrm{Al}>75^{\text {th }}$ percentile & $6.33(3.75-10.70)$ & $<0.0001$ & $6.31(3.67-10.84)$ & $<0.0001$ \\
\hline \multicolumn{5}{|l|}{ Women: } \\
\hline CETP B2 allele presence & $1.70(0.97-2.95)$ & 0.0609 & $1.75(0.81-3.79)$ & 0.1509 \\
\hline $\mathrm{BMI}<30 \mathrm{~kg} / \mathrm{m}^{2}$ & $2.02(1.08-3.78)$ & 0.0262 & $2.18(0.82-5.78)$ & 0.115 \\
\hline $\mathrm{TG} \leq 200 \mathrm{mg} / \mathrm{dl}$ & $5.11(0.67-38.91)$ & 0.1140 & $1.44(0.15-13.42)$ & 0.749 \\
\hline Apo $\mathrm{Al}>75^{\text {th }}$ percentile & $6.24(3.16-12.32)$ & $<0.0001$ & $6.15(3.08-12.27)$ & $<0.0001$ \\
\hline \multicolumn{5}{|l|}{ Men: } \\
\hline CETP B2 allele presence & $2.34(1.21-4.52)$ & 0.0113 & $1.59(0.60-4.18)$ & 0.3416 \\
\hline $\mathrm{BMI}<30 \mathrm{~kg} / \mathrm{m}^{2}$ & $5.38(2.16-13.39)$ & 0.0003 & $4.34(1.02-18.47)$ & 0.0446 \\
\hline $\mathrm{TG} \leq 200 \mathrm{mg} / \mathrm{dl}$ & $8.84(2.03-38.45)$ & 0.0035 & $8.79(0.91-84.82)$ & 0.0576 \\
\hline Apo $\mathrm{Al}>75^{\text {th }}$ percentile & $8.62(3.33-22.31)$ & $<0.0001$ & $10.48(3.51-31.27)$ & $<0.0001$ \\
\hline
\end{tabular}

For women the cut-off value of HDL cholesterol concentration $>75^{\text {th }}$ percentile was $70 \mathrm{mg} / \mathrm{dl}$. For men the cut-off value of HDL cholesterol concentration $>75^{\text {th }}$ percentile was $52 \mathrm{mg} / \mathrm{dl}$. For women the cut-off value of apo Al concentration $>75^{\text {th }}$ percentile was $177 \mathrm{mg} / \mathrm{dl}$. For men the cut-off value of apo Al concentration $>75^{\text {th }}$ percentile was $153 \mathrm{mg} / \mathrm{dl}$.

surements to be performed routinely in the clinical laboratory [39]. However, evaluation of the clinical usefulness of this assay is needed. Therefore, better understanding of the influence of genetic and metabolic or environmental factors and their interactions on HDL cholesterol could be helpful to more properly relate HDL cholesterol concentrations to clinical outcomes.

In the present study a significant influence of TaqIB polymorphism in the CETP gene on HDL cholesterol concentrations in subjects from the Polish population was documented. According to our knowledge, so far no reliable data on frequency of CETP-Taql and apo Al 75G/A genetic polymorphisms, and effects of these variants on HDL cholesterol as well as their interaction with other factors influencing HDL level in Polish adults, are available. Our previous preliminary study on the relationships between polymorphisms in CETP and apo Al genes and parameters of lipid metabolism were performed in a relatively small group of subjects [40,41]. Data of the present study are in agreement with previous reports indicating that the B2 allele is related to decreased CETP mass and activity, and increased HDL cholesterol concentrations and B1B1 carriers show the lowest and B2B2 carriers the highest HDL cholesterol concentrations [42, 43]. B2B2 genotype has been reported to be a protective factor against development of myocardial infarction, and B1B1 homozygotes are likely to have higher risk of CVD [44]. Our data indicate that carriers of the B2 allele of the CETP Taql polymorphism had 1.86 times higher chance of having high HDL cholesterol $\left(>75^{\text {th }}\right.$ percentile) than B1B1 homozygotes, while B1B1 homozygotes had 2.36 times higher risk of having low HDL cholesterol ( $<25^{\text {th }}$ percentile). However, subjects with low HDL cholesterol as compared to subjects with high HDL cholesterol are often characterized by high serum triglycerides and occurrence of small dense LDL particles as presented based on a very large database of lipids in US adults and children [45]. It underlines the important effect of disturbances in triglyceride-rich lipoprotein metabolism on HDL cholesterol [24]. In the present study obesity and hypertriglyceridemia (triglycerides > $200 \mathrm{mg} / \mathrm{dl}$ ) significantly modified the effect of CETP Taql polymorphism on HDL cholesterol. Obese subjects had lower HDL cholesterol levels than non-obese ones, but in obese carriers of the B2 allele HDL cholesterol concentrations were higher than in obese B1B1 homozygotes. Previously, it was suggested that the B2B2 genotype may protect against the HDL 
cholesterol lowering associated with obesity [46]. However, it can be hypothesized that even if in obese B2 allele carriers proper HDL cholesterol levels are observed, it may not be related to lower CVD risk. Obesity is commonly accompanied by raised serum triglycerides indicating raised levels of triglyceride rich-lipoproteins which can increase CVD risk $[47,48]$. In addition, an increased level of triglyceride-rich particles may be associated with an increased level of apo CIII, which can move to HDL and make HDL particles dysfunctional [29, 49 , 50]. Decreased CETP activity associated with the B2 genetic variant reduces removal of cholesterol and remodeling of HDL particles, which can result in accumulation of larger dysfunctional particles. Large HDL particles were found to be associated with increased CVD risk [51, 52].

Although obesity and hypertriglyceridemia significantly influence HDL cholesterol concentrations [50], our data show that in obese and hypertriglyceridemic subjects a significant effect of B1B1 homozygosity on having low HDL cholesterol is observed, as revealed by a multivariable logistic regression analysis. As obesity has become a worldwide epidemic and may reduce or even reverse the observed decline in myocardial infarction incidence and coronary heart disease mortality, the observed interaction between B1B1 homozygosity and obesity may significantly increase CVD risk and may have a significant impact on public health because of the high frequency of this genotype [53]. In addition, the present study indicates that the impact of the B2 allele of the CETP-Taql polymorphism on having high $\mathrm{HDL}$ cholesterol does not seem to be significant when levels of apo $\mathrm{Al}$ and triglycerides and $\mathrm{BMI}$ are taken into consideration. A significant association between CETP genetic variants causing high HDL cholesterol concentrations and reduced cardiovascular disease risk was reported [54]. However, carriers of the HDL-increasing CETP alleles were characterized by significantly lower LDL cholesterol and serum triglyceride concentrations. Therefore, the impact of genetic, metabolic and environmental factors affecting triglyceride-rich lipoprotein metabolism on HDL cholesterol levels appeared to be more important than the impact of genetic factors causing increased HDL cholesterol levels [55].

There are fewer available data concerning the apo Al Mspl (75G/A) polymorphism. The A allele was found to be related to an increase of Apo Al gene expression and serum apo Al concentrations [56]. It was reported that the A allele was a major contributor to inter-individual variability in plasma cholesterol efflux capacity in women [57], and subjects carrying this allele had increased circulating levels of small HDL particles [58]. In the present study no significant influence of $75 \mathrm{G} / \mathrm{A}$ variants in the apo Al gene on HDL cholesterol was found. Statistical analyses revealed that only in nonobese women was occurrence of the A allele associated with significantly increased HDL cholesterol levels, but the effect of this allele did not persist when in statistical analysis other confounders (such as CETP genetic variants, obesity and hypertriglyceridemia) were taken into account. It seems that the potential influence of $75 \mathrm{G} / \mathrm{A}$ variants is significantly masked by different genetic, metabolic and environmental factors.

In conclusion, the present study indicates a significant impact of the TaqlB polymorphism in the CETP gene on HDL cholesterol levels in the Polish population, while the effect of the $75 \mathrm{G} / \mathrm{A}$ polymorphism in the apo Al gene appears not to be significant. Obesity and hypertriglyceridemia significantly interact with CETP Taql variants by increasing the chance of having low HDL cholesterol.

\section{Acknowledgments}

This work was supported by the National Science Centre (grant numbers: NN404087940, 2011/01/N/NZ7/04559) and was carried out using CePT infrastructure financed by the European Union - the European Regional Development Fund within the Operational Program (Innovative Economy for 2007-2013).

\section{Conflict of interest}

The authors declare no conflict of interest.

\section{References}

1. Libby P. Changing concepts of atherogenesis. J Intern Med 2000; 247: 349-58.

2. Lusis AJ. Atherosclerosis. Nature 2000; 407: 233-41.

3. Goff DC Jr, Lloyd-Jones DM, Bennett G, et al. 2013 ACC/ AHA guideline on the assessment of cardiovascular risk: a report of the American College of Cardiology/American Heart Association Task Force on Practice Guidelines. Circulation 2014; 129: S49-73.

4. Barylski M, Toth PP, Nikolic D, Banach M, Rizzo M, Montalto G. Emerging therapies for raising high-density lipoprotein cholesterol (HDL-C) and augmenting HDL particle functionality. Best Pract Res Clin Endocrinol Metab 2014; 28: 453-61.

5. Ray KK, Cannon CP, Cairns R, Morrow DA, Ridker PM, Braunwald E. Prognostic utility of apoB/Al, total cholesterol/HDL, non-HDL cholesterol, or hs-CRP as predictors of clinical risk in patients receiving statin therapy after acute coronary syndromes: results from PROVE IT-TIMI 22. Arterioscler Thromb Vasc Biol 2009; 29: 424-30.

6. Ridker PM, Genest J, Boekholdt SM, et al. Group JTS. $\mathrm{HDL}$ cholesterol and residual risk of first cardiovascular events after treatment with potent statin therapy: an analysis from the JUPITER trial. Lancet 2010; 376: 333-9.

7. Group HTC, Landray MJ, Haynes R, et al. Effects of extended-release niacin with laropiprant in high-risk patients. N Engl J Med 2014; 371: 203-12. 
8. Dragan S, Serban C, Banach M. Can we change the functionality of HDL cholesterol with nonpharmacological and pharmacological agents? Curr Med Chem 2014; 21 : 2927-46.

9. Nowicka G, Jarosz A. LpAI in HDL subfractions: serum levels in men and women with coronary heart disease and changes under hypolipemic therapy. Clin Chim Acta 2001; 306: 43-9.

10. Kathiresan S, Melander O, Anevski D, et al. Polymorphisms associated with cholesterol and risk of cardiovascular events. N Engl J Med 2008; 358: 1240-9.

11. Radovica I, Fridmanis D, Vaivade I, Nikitina-Zake L, Klovins J. The association of common SNPS and haplotypes in CETP gene with HDL cholesterol levels in Latvian population. PLoS One 2013; 8: e64191.

12. Juo SH, Wyszynski DF, Beaty TH, Huang HY, Bailey-Wilson JE. Mild association between the A/G polymorphism in the promoter of the apolipoprotein A-I gene and apolipoprotein A-I levels: a meta-analysis. Am J Med Genet 1999; 82: 235-41.

13. Toth PP, Barter PJ, Rosenson RS, et al. High-density lipoproteins: a consensus statement from the National Lipid Association. J Clin Lipidol 2013; 7: 484-525.

14. Cole CB, Nikpay M, Lau P, et al. Adiposity significantly modifies genetic risk for dyslipidemia. J Lipid Res 2014; 55: 2416-22.

15. de Grooth GJ, Klerkx AH, Stroes ES, Stalenhoef AF, Kastelein JJ, Kuivenhoven JA. A review of CETP and its relation to atherosclerosis. J Lipid Res 2004; 45: 1967-74.

16. Funder JW. Aldosterone, sodium, and hypertension: lessons from torcetrapib? Hypertension 2010; 55: 221-3.

17. Schwartz GG, Olsson AG, Abt M, et al. Effects of dalcetrapib in patients with a recent acute coronary syndrome. N Engl J Med 2012; 367: 2089-99.

18. Ridker PM, Pare G, Parker AN, Zee RY, Miletich JP, Chasman DI. Polymorphism in the CETP gene region, HDL cholesterol, and risk of future myocardial infarction: genomewide analysis among 18245 initially healthy women from the Women's Genome Health Study. Circ Cardiovasc Genet 2009; 2: 26-33.

19. Thompson A, Di Angelantonio E, Sarwar N, et al. Association of cholesteryl ester transfer protein genotypes with CETP mass and activity, lipid levels, and coronary risk. JAMA 2008; 299: 2777-88.

20. Voight BF, Peloso GM, Orho-Melander $M$, et al. Plas ma HDL cholesterol and risk of myocardial infarction: a mendelian randomisation study. Lancet 2012; 380: 572-80.

21. Regieli JJ, Jukema JW, Grobbee DE, et al. CETP genotype predicts increased mortality in statin-treated men with proven cardiovascular disease: an adverse pharmacog enetic interaction. Eur Heart J 2008; 29: 2792-9.

22. Mohrschladt MF, van der Sman-de Beer F, Hofman MK, van der Krabben M, Westendorp RG, Smelt AH. TaqIB polymorphism in CETP gene: the influence on incidence of cardiovascular disease in statin-treated patients with familial hypercholesterolemia. Eur J Hum Genet 2005; 13: 877-82

23. Pulkkinen A, Viitanen L, Kareinen A, Lehto S, Laakso $M$ Mspl polymorphism at +83 bp in intron 1 of the human apolipoprotein A1 gene is associated with elevated levels of HDL cholesterol and apolipoprotein A1 in nondiabetic subjects but not in type 2 diabetic patients with coronary heart disease. Diabetes Care 2000; 23: 791-5.

24. Tenenbaum A, Klempfner R, Fisman EZ. Hypertriglyceri demia: a too long unfairly neglected major cardiovascular risk factor. Cardiovasc Diabetol 2014; 13: 159.
25. National Cholesterol Education Program Expert Panel on Detection E, Treatment of High Blood Cholesterol in A: Third Report of the National Cholesterol Education Program (NCEP) Expert Panel on Detection, Evaluation, and Treatment of High Blood Cholesterol in Adults (Adult Treatment Panel III) final report. Circulation 2002; 106: 3143-421.

26. Dobiasova M. Atherogenic index of plasma [log(triglycerides/HDL-cholesterol)]: theoretical and practical implications. Clin Chem 2004; 50: 1113-5.

27. Cannon $\mathrm{CP}$, Braunwald $\mathrm{E}, \mathrm{McC}$ abe $\mathrm{CH}$, et al. Intensive versus moderate lipid lowering with statins after acute coronary syndromes. N Engl J Med 2004; 350: 1495-504.

28. Downs JR, Clearfield M, Weis S, et al. Primary prevention of acute coronary events with lovastatin in men and women with average cholesterol levels: results of AFCAPS/TexCAPS. Air Force/Texas Coronary Atherosclerosis Prevention Study. JAMA 1998; 279: 1615-22.

29. Kones R. Molecular sources of residual cardiovascular risk, clinical signals, and innovative solutions: relationship with subclinical disease, undertreatment, and poor adherence: implications of new evidence upon optimizing cardiovascular patient outcomes. Vasc Health Risk Manag 2013; 9: 617-70.

30. Boden WE. High-density lipoprotein cholesterol as an independent risk factor in cardiovascular disease: assessing the data from Framingham to the Veterans Affairs High--Density Lipoprotein Intervention Trial. Am J Cardiol 2000; 86: 19L-22L.

31. Barter P, Gotto AM, LaRosa JC, et al.; Treating to New Targets I. HDL cholesterol, very low levels of LDL cholesterol, and cardiovascular events. N Engl J Med 2007; 357: 1301-10

32. Assmann G, Gotto AM Jr. HDL cholesterol and protective factors in atherosclerosis. Circulation 2004; 109: III8-14.

33. Noone E, Roche HM, Black I, Tully AM, Gibney MJ. Effect of postprandial lipaemia and Taq $1 B$ polymorphism of the cholesteryl ester transfer protein (CETP) gene on CETP mass, activity, associated lipoproteins and plasma lipids. Br J Nutr 2000; 84: 203-9.

34. Feitosa MF, Wojczynski MK, Straka R, et al. Genetic analysis of long-lived families reveals novel variants influencing high density-lipoprotein cholesterol. Front Genet 2014; 5: 159.

35. Agouridis AP, Banach M, Mikhailidis DP. Dysfunctional high-density lipoprotein: not only quantity but first of all quality? Arch Med Sci 2015; 11: 230-1.

36. Parish S, Offer A, Clarke R, et al.; Heart Protection Study Collaborative $\mathrm{G}$. Lipids and lipoproteins and risk of different vascular events in the MRC/BHF Heart Protection Study. Circulation 2012; 125: 2469-78.

37. Mora S, Glynn RJ, Ridker PM. High-density lipoprotein cholesterol, size, particle number, and residual vascular risk after potent statin therapy. Circulation 2013; 128: 1189-97.

38. Mackey RH, Greenland P, Goff DC Jr, Lloyd-Jones D, Sibley CT, Mora S. High-density lipoprotein cholesterol and particle concentrations, carotid atherosclerosis, and coronary events: MESA (multi-ethnic study of atherosclerosis). J Am Coll Cardiol 2012; 60: 508-16.

39. Matyus SP, Braun PJ, Wolak-Dinsmore J, et al. HDL particle number measured on the Vantera(R), the first clinical NMR analyzer. Clin Biochem 2015; 48: 148-55.

40. Pachocka LM, Wlodarczyk M, Nowicka G, KlosiewiczLatoszek L, Wolanska D, Stolarska I. CETP gene TaqIB polymorphism and plasma lipids in patients with overweight and obesity. Rocz Panstw Zakl Hig 2012; 63: 149-54. 
41. Włodarczyk M. Wrzosek M, Nowicka G. Impact of 75G/A apolipoprotein Al gene polymorphism on lipid profile in obese and non-obese men. Pol J Hum Nutr Metabol 2014; 41: 69-77.

42. Kaman D, Ilhan N, Ilhan N, Akbulut M. TaqIB and severity of coronary artery disease in the Turkish population: a pilot study. Bosn J Basic Med Sci 2015; 15: 9-13.

43. Vohl MC, Lamarche B, Pascot A, et al. Contribution of the cholesteryl ester transfer protein gene TaqIB polymorphism to the reduced plasma HDL-cholesterol levels found in abdominal obese men with the features of the insulin resistance syndrome. Int J Obes Relat Metab Disord 1999; 23: 918-25.

44. Cao M, Zhou ZW, Fang BJ, Zhao CG, Zhou D. Meta-analysis of cholesteryl ester transfer protein TaqIB polymorphism and risk of myocardial infarction. Medicine (Baltimore) 2014; 93: e160.

45. Quispe R, Al-Hijji M, Swiger KJ, et al. Lipid phenotypes at the extremes of high-density lipoprotein cholesterol: the very large database of lipids-9. J Clin Lipidol 2015; 9: e511-18.

46. Hodoglugil U, Mahley RW. Smoking and obesity make a bad problem worse: genetics and lifestyle affect high density lipoprotein levels in Turks. Anadolu Kardiyol Derg 2006; 6: 60-7.

47. Chapman MJ, Ginsberg HN, Amarenco P, et al. Triglyceride-rich lipoproteins and high-density lipoprotein cholesterol in patients at high risk of cardiovascular disease: evidence and guidance for management. Eur Heart J 2011; 32: 1345-61.

48. Corella D, Carrasco P, Fito M, et al. Gene-environment interactions of CETP gene variation in a high cardiovascular risk Mediterranean population. J Lipid Res 2010; 51: 2798-807.

49. Jensen MK, Rimm EB, Furtado JD, Sacks FM. Apolipoprotein C-III as a potential modulator of the association between HDL-cholesterol and incident coronary heart disease. J Am Heart Assoc 2012; 1: pii: jah3-e000232. doi: 10.1161/JAHA.

50. Zaki ME, El-Bassyouni HT, El-Gammal M, Kamal S. Indicators of the metabolic syndrome in obese adolescents. Arch Med Sci 2015; 11: 92-8.

51. Sam S, Haffner S, Davidson MH, D’Agostino R Sr, Perez A Mazzone T. Pioglitazone-mediated changes in lipoprotein particle composition are predicted by changes in adiponectin level in type 2 diabetes. J Clin Endocrinol Metab 2012; 97: E110-4.

52. Rizzo M, Otvos J, Nikolic D, Montalto G, Toth PP, Banach M. Subfractions and subpopulations of HDL: an update. Curr Med Chem 2014; 21: 2881-91.

53. Hardoon SL, Morris RW, Whincup PH, et al. Rising adiposity curbing decline in the incidence of myocardial infarction: 20-year follow-up of British men and women in the Whitehall II cohort. Eur Heart J 2012; 33: 478-85.

54. Johannsen TH, Frikke-Schmidt R, Schou J, Nordestgaard BG, Tybjaerg-Hansen A. Genetic inhibition of CETP, ischemic vascular disease and mortality, and possible adverse effects. J Am Coll Cardiol 2012; 60: 2041-8.

55. Do R, Willer CJ, Schmidt EM, et al. Common variants associated with plasma triglycerides and risk for coronary artery disease. Nat Genet 2013; 45: 1345-52.

56. Angotti E, Mele E, Costanzo F, Avvedimento EV. A polymorphism (G-->A transition) in the -78 position of the apolipoprotein A-I promoter increases transcription efficiency. J Biol Chem 1994; 269: 17371-4.

57. Villard EF, EI Khoury P, Frisdal E, et al. Genetic determination of plasma cholesterol efflux capacity is gender-spe- cific and independent of HDL-cholesterol levels. Arterioscler Thromb Vasc Biol 2013; 33: 822-8.

58. Tsai MY, Ordovas JM, Li N, et al. Effect of fenofibrate therapy and $A B C A 1$ polymorphisms on high-density lipoprotein subclasses in the Genetics of Lipid Lowering Drugs and Diet Network. Mol Genet Metab 2010; 100: 118-22. 